\section{$\mathbf{V} \mathbf{M}$ \\ VIA MEDICA \\ www.fr.viamedica.pl}

\title{
Calciphylaxis — pathogenesis and clinical picture
}

\section{ABSTRACT}

Calciphylaxis, also known as calcific uremic arteriolopathy (CUA), is a rare vascular disease caused by deposition of calcium salts in vessel walls, accompanied by coagulation disorders, which leads to extensive skin ulceration and soft tissue necrosis. Typical cases of calciphylaxis are usually described in patients with renal failure, though it is currently known that approx. 1/10th of all cases stem from other causes, including systemic inflammation, metabolic disorders and endocrine disorders. This article shows an overview of the most important pathophysiological phenomena which accompany calciphylaxis, characterizes the clinical picture of the disease and presents available approaches to therapeutic management.

Forum Reumatol. 2019, tom 5, nr 1: 14-20

Key words: calciphylaxis; vasculitis; end-stage renal disease
Adres do korespondencji: dr hab. n. med. Przemysław Kotyla Chair and Clinic of Internal Medicine and Rheumatology Medical University of Silesia in Katowice ul. Ziołowa $45 / 47$ 40-635 Katowice e-mail: pkotyla@sum.edu.pl

\section{INTRODUCTION}

Calciphylaxis, also known as calcific uremic arteriolopathy (CUA), was first described in the $18^{\text {th }}$ century. Contemporary description and knowledge of the pathogenic basis stems from work done by Hans Selye, who in 1962 conducted an experiment on laboratory animals recreating pathogenic phenomena which occur during calciphylaxis in humans $[1,2]$. It is a relatively rare disease described mainly in patients with end-stage renal disease, patients who undergo dialysis and, somewhat atypically, in patients after a kidney transplant [3].

Clinical picture is reminiscent of severe necrotizing vasculitis with deep destruction of subcutaneous tissue and formation of non-healing ulcers. However, literature does contain descriptions of cases which are unrelated to kidney failure, with emphasis placed on such factors as pro-inflammatory mechanisms, endothelial damage or loss of balance between activators and inhibitors of extraskeletal calcification $[4,5]$.
This article shows an overview of the most important pathogenic phenomena in calciphylaxis, indicating the differences in the course of the disease in patients with functional kidneys and emphasizing the role of primary cellular inflammatory pathways, which participate, at least partially, in pathogenesis of this rare disease.

\section{CLINICAL PICTURE}

Clinical picture of calciphylaxis is reminiscent of severe necrotizing vasculitis with accompanying skin and subcutaneous tissue necrosis and formation of deep, exuding ulcers, whose bottom is typically covered with necrotic masses which form black eschars. $\mathrm{Cu}-$ taneous lesions exhibit a degree of phasicity. They typically begin as livedo reticularis and then evolve to nodular cutaneous thickenings, which subsequently undergo necrosis and form deep, penetrating ulcers [6].

Typical descriptions of calciphylaxis come from patients who undergo dialysis and patients with end-stage renal disease, though 
there are recorded instances in patients after a kidney transplant [4]. Calcium and phosphate metabolism disorders and hyperparathyroidism (including primary) which accompany renal diseases and long-term dialysis treatment are considered the most important pathogenic factors of the disease [7]. However, analysis of patient registers from USA and Europe reveals that renal diseases, though typically present in calciphylaxis patients, do not account for all cases of this disease. It is estimated that in approx. $10 \%$ of calciphylaxis patients no renal disease is found, and vessel damage progresses regardless of functional status of kidneys. Such cases are referred to as non-uremic calciphylaxis [8]. Their causal mechanism likely involves other phenomena related to chronic inflammation, coagulation disorders and endothelial damage.

\section{DIAGNOSIS}

Clinical diagnosis is exceptionally difficult, as the clinical course of this relatively rare disease is similar to typical necrotizing vasculitis. It can also be assumed that the low frequency of calciphylaxis diagnosis is at least in part caused by calciphylaxis being mistakenly classified as treatment-resistant vasculitis. This is why correctly collected medical history (renal failure, dialysis treatment, primary and secondary hyperparathyroidism, hypervitaminosis $\mathrm{D}_{3}$ ) is vital [9]. However, final diagnosis can only be made after collecting biopsy specimens of affected skin and proving the presence of typical histopathological changes. These changes include skin and subcutaneous tissue necrosis and inflammatory infiltrate in the adipose tissue. Discovery of calcium salt incrustations within the affected vessels, accompanied by media hyperplasia, media fibrosis and thrombotic lesions within the vessels, is the most characteristic and valuable in terms of diagnosis [10] (Table 1).

However, histopathological examination, though providing a virtually indisputable dia- gnosis, can be fairly controversial in clinical practice. This is because in patients with calciphylaxis, the healing process for even small surgical wounds is considerably hindered, which means that there is risk of further skin damage and exacerbation of ischemic cutaneous lesions. For this reason, alternative methods, such as vascular ultrasound which would indicate accumulation of calcium salts in vessel walls, detection of inflammatory foci in the adipose tissue, skeletal scintigraphy, or a regular $\mathrm{x}$ -ray examination of the extremities which would indicate calcium saturation of vessel walls and bead-like calcium salt deposits along the vessel routes, are being researched [11].

\section{RISK FACTORS}

On the basis of available data from literature, including descriptions of individual cases and characteristics of limited case series, it was possible to identify risk factors which may be involved in pathogenesis of the disease. They include, apart from the already mentioned renal failure, certain types of cancer, alcohol-induced liver injury, inflammatory joint diseases and systemic connective tissue diseases. Renal failure, as well as long-term dialysis treatment, may be responsible for the process of vessel wall calcification [12]. The course of renal failure is marked by increased phosphate retention, secondary hyperparathyroidism and calcium salt substitution. Excessive administration of phosphate-binding calcium preparations and inadequately chosen composition of dialysis fluids may contribute to development of calciphylaxis in predisposed patients. It is therefore not surprising that typical descriptions of calciphylaxis concern patients with end-stage renal disease and patients who undergo dialysis $[4,13]$. On the basis of analysis of calcium and phosphate concentrations it was estimated that the risk of disease is particularly high when the calcium $\mathrm{X}$ phosphate product exceeds $60 \mathrm{mg}^{2} / \mathrm{dL}^{2}$. Analyses of medical registers indicate that the risk of this

Table 1. For and against mineral metabolism disorders in pathogenesis of calciphylaxis

\begin{tabular}{|l|l|}
\hline Yes & No \\
\hline Renal failure & Occurs also in patients with no renal failure \\
\hline Mineral metabolism disorders & Is exacerbated after administration of oral anticoagulants \\
\hline Metabolic disorders & Female gender \\
\hline Incrustation of vascular wall with calcium salts & Occurs in the course of systemic CTDs (SLE) \\
\hline Poor response to steroids and immunosuppressants & Histopathological examination — thrombosis \\
\hline
\end{tabular}


complication is 3.5/1000 patient-years among patients with end-stage renal disease [14]. According to German registers, approx. 30 new cases are recorded annually within the renal failure patient group; a similar number of cases should be assumed for Poland [15].

However, not all cases are recorded in patients with severely impeded renal function; approx. $10 \%$ of all cases of calciphylaxis occur in patients with normal or only slightly impeded renal function, in whom serious disorders on the calcium-phosphorus-parathyroid glands axis should not be expected. The already cited German register of instances of calciphylaxis shows that as many as $20 \%$ of all cases of calciphylaxis occur in patients whose GFR is above $60 \mathrm{ml} / \mathrm{min}$ [15]. Unfortunately, at the moment we do not have access to clinical characteristics of patients with calciphylaxis in the course of renal diseases versus patients with preserved renal function. It is therefore difficult to draw any conclusions. However, it can be conjectured that patients with renal failure and patients with preserved renal function may comprise two distinct clinical entities with a similar nosological picture. This shows the need to also take other disease mechanisms into account. Other risk factors were also identified for this patient group, including metabolic disorders (e.g. obesity, diabetes), chronic inflammations (inflammation related to alcohol-induced liver injury), administration of certain types of drugs (immunosuppressants, cytostatics, glucocorticoids) and occurrence of autoimmune phenomena [16-19]. A list of currently known risk factors can be found in Table 2.

\section{DIFFERENTIATION}

Clinical picture is reminiscent of a very active, aggressive vasculitis with skin necrosis and deep ulceration. Both diseases are virtually indistinguishable clinically, so diagnosis is based on results of a histopathological examination and demonstration of calcium deposits within the media. Arterial wall calcification forces differentiation between calciphylaxis and atherosclerosis: in the latter, calcification occurs intravascularly and is related to presence of atheromatous plaques, while in calciphylaxis, calcification concerns the media. Taking into account the diameter of affected vessels it should be noted that lesions typical for calciphylaxis concern vessels of less than $0.6 \mathrm{~mm}$ in diameter, cutaneous
Table 2. Causes of non-uremic calciphylaxis

\begin{tabular}{|l|}
\hline Causes of non-uremic calciphylaxis \\
\hline Hyperparathyroidism \\
\hline Cancers \\
- Gallbladder \\
- Chronic myeloid leukaemia \\
- Malignant melanoma \\
- Other cancers \\
\hline Alcohol-induced liver injury \\
\hline Systemic connective tissue diseases \\
- Lupus \\
- RA \\
- Temporal arteritis \\
- Antiphospholipid syndrome \\
\hline Diabetes \\
\hline Obesity \\
\hline POEMS syndrome \\
\hline Female gender \\
\hline Drugs: \\
\hline - Immunosuppressants \\
- Glucocorticoids \\
\hline
\end{tabular}

arterioles and capillaries to the same degree, with typical calcium deposits in the media. Uncharacteristic clinical picture forces broad differentiation between all nosological entities whose course is marked by potential extensive skin damage [20-22] (Table 3).

\section{PATHOGENESIS}

End-stage renal disease and related metabolic disorders play the biggest role in commencing vascular destruction. However, such understanding of the disease is a gross oversimplification [4]. Damaging processes begin at the media level Figure 1. They are accompanied by such phenomena as hypercoagulability and increased readiness of the body to form extraskeletal calcification areas. Tissue calcification processes are regulated by an efficient mechanism for prevention of formation of extraskeletal mineralization areas. This system is comprised primarily of matrix Gla protein (MGP), a strong inhibitor of bone morphogenetic protein 2 (BMP-2); BMP-2 is involved in extraskeletal calcification [15, 23, 24]. This efficient mechanism works only for post-translational MGP modification, which takes place via gamma-carboxylation of proteins. Vitamin $\mathrm{K}$, which is a gamma-carboxylase cofactor, takes part in this process (much like in the case of coagulation factors). In cases of vitamin $\mathrm{K}$ deficiency, or, more often, of administration of 
Table 3. Differential diagnosis of calciphylaxis

\begin{tabular}{|l|l|}
\hline \multicolumn{2}{|l|}{ Differential diagnosis of calciphylaxis } \\
\hline Warfarin-induced skin necrosis & Subsides after warfarin is discontinued \\
\hline Antiphospholipid syndrome & $\begin{array}{l}\text { Typical constellation of clinical and laboratory symptoms with presence of antibo- } \\
\text { dies }\end{array}$ \\
\hline Small vessel atherosclerosis & Weak/no pulse, cold extremities, intermittent claudication \\
\hline Post-traumatic ulceration & $\begin{array}{l}\text { Irregular shape, typically no livedo reticularis, history of trauma, usually located on } \\
\text { the anterior lower leg surface }\end{array}$ \\
\hline Ulceration with venous insufficiency & $\begin{array}{l}\text { Irregular shape, bottom covered with wet fibrin, varices of lower extremities, hemo- } \\
\text { siderin deposits in surrounding skin }\end{array}$ \\
\hline Neuropathic ulceration & $\begin{array}{l}\text { Ulceration located in places where pressure was applied, irregularities found during } \\
\text { neurological examination (sensory disorders: tactile, vibration, thermal), occasio- } \\
\text { nally Charcot joint-type deformities }\end{array}$ \\
\hline Systemic vasculitis & $\begin{array}{l}\text { Symptoms of a systemic nature affecting internal organs, positive anti-neutrophil } \\
\text { cytoplasmic antibodies (ANCAs) }\end{array}$ \\
\hline Heparin-induced skin necrosis & $\begin{array}{l}\text { Appears approx. 2 weeks after heparin treatment is commenced, primarily in } \\
\text { places of heparin injections, accompanied by significant reduction in platelet count } \\
\text { (<50,000) }\end{array}$ \\
\hline Cryoglobulinemia & Affects medial and/or lateral thigh surface, changes in protein electrophoresis \\
\hline $\begin{array}{l}\text { Disseminated intravascular coagula- } \\
\text { tion }\end{array}$ & $\begin{array}{l}\text { Disseminated skin lesions with thrombocytopenia and significantly increased } \\
\text { D-dimer concentration, material changes in laboratory test results, lesions of } \\
\text { a systemic nature }\end{array}$ \\
\hline phrombotic thrombocytopenic & $\begin{array}{l}\text { Begins distally, shows tendencies to proximal spreading, significantly reduced } \\
\text { platelet count, high LDH activity }\end{array}$ \\
\hline
\end{tabular}

anticoagulants, which are competitive vitamin $\mathrm{K}$ inhibitors, the carboxylation process is not fully realised, and MGPs are either not carboxylated at all or are carboxylated only partially. Other extraskeletal calcification inhibitors include fetuin and osteocalcin, wherein only the former plays a role in vascular calcification processes [24]. Osteocalcin's action is of a more systemic nature, and the molecule is too big to take part in local calcification inhibition [25].

Analysing images of affected vessels reveals specific arrangement of calcium salts, which differentiates this disease from vasculopathy during the course of osteodystrophy or typical atheromatous plaques undergoing calcification. Unlike the other two, in calciphylaxis, this process concerns the media, and is preceded by a change in phenotype of the vessel's smooth muscle cells towards osteoblast-like cells. Osteoblast-like cells are characterized by considerable sensitivity to factors which determine increased tissue mineralization. This process is also regulated by osteopontin and bone morphogenetic protein 4 (BMP-4), which participate in development and bone damage repair processes, and are also considered indicators of cell transformation towards osteoblasts. Osteopontin concentration is regulated by NF- $\kappa \mathrm{B}$ transcription factor, whose activity increases due to pro-inflammatory cytokines and free radicals.

Such presentation of pathogenic processes moves the understanding of calciphylaxis closer to regular crystal arthropathy (name created do emphasize similarities to crystal arthropathy, as both diseases are dominated by deposition of calcium salts in, respectively, vascular walls and synovial membranes of joints) Table 1.

In light of recent reports, such mechanistic understanding of the disease is a gross oversimplification. New light on understanding of pathogenesis of the disease was shed by observations indicating very high frequency of coagulation disorders (approx. 60\% of all cases of calciphylaxis) and increased procoagulation activity (related to e.g. coagulation inhibitor deficiency or other form of thrombophilia). Among discovered coagulation disorders, of particular note are antithrombin deficiency $(50 \%)$, followed by deficiencies in activity of $\mathrm{C}$ and $\mathrm{S}$ proteins (38\% and $43 \%$, respectively). A change in the endothelial state from anticoagulant to procoagulant may also be caused by local action of pro-inflammatory cytokines, especially IL-11, IL-6 and TNF-alpha. Increased concentrations of these cytokines may stem from a systemic inflammatory process or from metabolic or endocrine disorders (Fig. 1). 


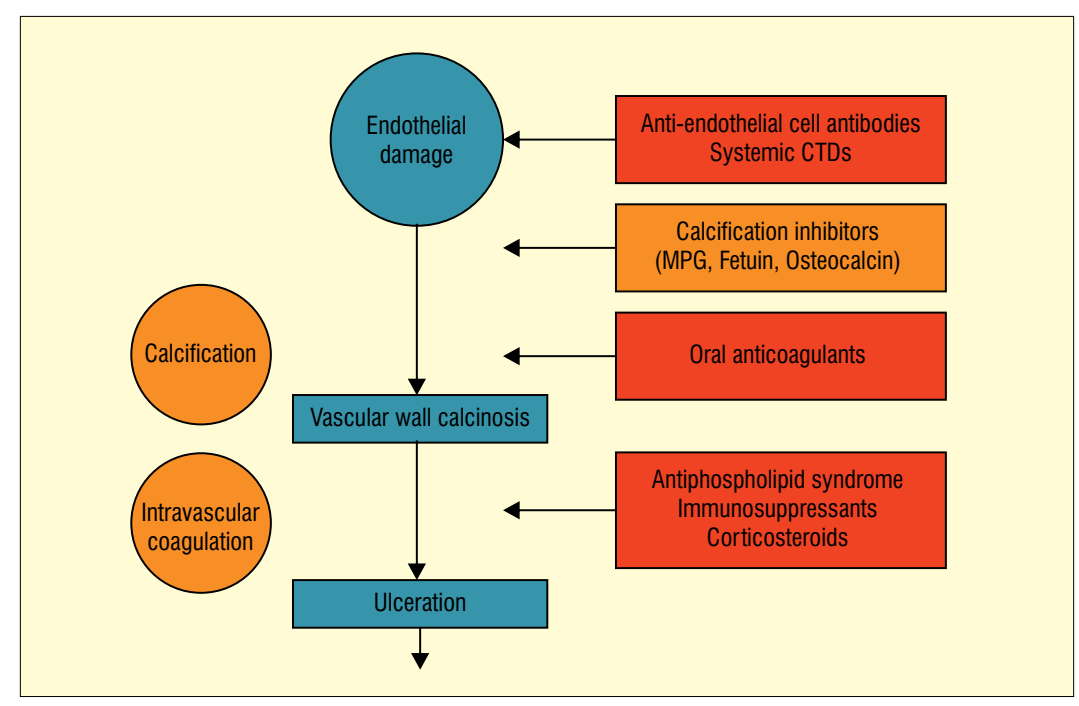

Figure 1. The role of endothelium in development of calciphylaxis

\section{IMPORTANCE OF VITAMIN K}

As mentioned, most patients with calciphylaxis are diagnosed with blood coagulation disorders and often have a history of severe ischemic episodes. Due to this, and for other, typically cardiologic, reasons, these patients receive appropriate anticoagulation treatment based primarily on vitamin $\mathrm{K}$ antagonists. However, it emerges that administration of vitamin $\mathrm{K}$ antagonists significantly exacerbates vascular lesions, and the group treated in this manner is characterized by more severe progression and less fav ourable prognosis. Pathogenic basis of adverse effects of vitamin $\mathrm{K}$ antagonists stems from the fact that vitamin K's action as a gamma-carboxylation cofactor is blocked and protective action of calcification inhibitors (primarily MGP), which must also undergo carboxylation to maintain their physiological effect, is suppressed. If anticoagulation treatment is necessary, it is recommended to use direct anticoagulants which act at the thrombin level and bypass vitamin K-dependent coagulation factor phases.

\section{PROGNOSIS}

Calciphylaxis is a potentially fatal disease - half of patients die within the first year, while only $1 / 5$ th survive two years. Septic complications, caused by extensiveness of non-healing wounds, are the most common causes of death. Although there are no differences in survival curves between patients with proximal lesions and patients with peripheral lesions, patients with both types of lesions are charac- terized by a much less favourable prognosis (this is likely due to extensiveness of skin damage). Patients with calcification within the penis area are also characterized by markedly increased mortality within 1 year $(69 \%)$. The cause of this phenomenon is unknown.

\section{TREATMENT}

1. In treatment, controlling the inflammation is crucial; this can be realized by utilizing:

- Broad-spectrum antibiotic therapy;

- Excisional debridement of wounds [26];

- Hyperbaric chamber treatment [27].

2. Pain relief is a very important element of therapeutic management:

- due to dramatic progression, it is recommended to administer opiates, avoiding morphine if possible, as it can further reduce tissue perfusion. Fentanyl is the drug of choice, and can be supplemented by another opiate when it is time to change bandages.

3. Keeping in mind the high frequency of coagulation disorders, anticoagulation treatment can be considered a basic element of medical management. Specific adverse effects of vitamin $\mathrm{K}$ antagonists in calciphylaxis patients have to be taken into account:

- oral anticoagulants are contraindicated in the course of calciphylaxis. Heparin may be administered if anticoagulation treatment is necessary, and drugs which directly affect prothrombin complex can be used if long-term treatment is required. 
4. Counteracting mineral metabolism disorders:

- in cases of calciphylaxis dependant on imbalance on the calcium-phosphorus-parathormone axis, restoring the balance is necessary. To reduce calcium concentration, administration of so-called calcimimetics, i.e. drugs which sensitise the calcium-sensing receptors and cause calcium levels to drop, is worth considering. Good results can be achieved by utilizing sodium thiosulfate infusions at a dose of $25 \mathrm{~g} 3$ times a week [23]. In case of patients who undergo dialysis, changing the dialysis programme, modifying the composition of the dialysis fluid and changing the method of dialysis (haemodialysis is preferred over peritoneal dialysis) should be considered [28-31].

\section{CONCLUSIONS}

Calciphylaxis is a rare disease described mainly in patients with end-stage renal disease, in whom severe mineral metabolism disorders are the causal factor. Approx. $10 \%$ of all cases of calciphylaxis occur in patients with functional kidneys, which shows that calcium-phosphate axis disorders are not a universal pathogenic mechanism. The disease requires a broad differential approach, which should take into account all diseases whose course is marked by skin necrosis. If calciphylaxis is suspected, vitamin $\mathrm{K}$ antagonists should be avoided and glucocorticoids as well as immunosuppressants should not be administered due to risk of exacerbation of the nosological picture.
1. Selye H, Gentile G, Prioreschi P. Cutaneous Molt Induced by Calciphylaxis in the Rat. Science. 1961; 134(3493): 1876-1877, doi: 10.1126/science.134.3493.1876.

2. Rees JK, Coles GA. Calciphylaxis in man. Br Med J. 1969; 2(5658): 670-672, indexed in Pubmed: 5783125.

3. Wilmer WA, Magro CM. Calciphylaxis: emerging concepts in prevention, diagnosis, and treatment. Semin Dial. 2002; 15(3): 172-186, indexed in Pubmed: 12100455.

4. Fernández $M$, Morales $E$, Gutierrez $E$, et al. Calciphylaxis: Beyond CKD-MBD. Nefrologia. 2017; 37(5): 501-507, doi: 10.1016/j.nefro.2017.02.006, indexed in Pubmed: 28390776.

5. Lee JL, Naguwa SM, Cheema G, et al. Recognizing calcific uremic arteriolopathy in autoimmune disease: an emerging mimicker of vasculitis. Autoimmun Rev. 2008; 7(8): 638-643, doi: 10.1016/.autrev.2008.02.003, indexed in Pubmed: 18774119

6. Daudén $\mathrm{E}$, Oñate MJ. Calciphylaxis. Dermatol Clin. 2008; 26(4): 557-68, ix, doi: 10.1016/j.det.2008.05.006, indexed in Pubmed: 18793990.

7. Nigwekar SU, Kroshinsky D, Nazarian RM, et al. Calciphylaxis: risk factors, diagnosis, and treatment. Am J Kidney Dis. 2015; 66(1): 133-146, doi: 10.1053/j. ajkd.2015.01.034, indexed in Pubmed: 25960299.

8. Nigwekar SU, Wolf M, Sterns RH, et al. Calciphylaxis from nonuremic causes: a systematic review. Clin J Am Soc Nephrol. 2008; 3(4): 1139-1143, doi: 10.2215/CJN.00530108, indexed in Pubmed: 18417747.

9. Ghosh T, Winchester DS, Davis MDP, et al. Early clinical presentations and progression of calciphylaxis. Int J Dermatol. 2017; 56(8): 856-861, doi: 10.1111/ijd.13622, indexed in Pubmed: 28436018

10. Kossard S, Winkelmann RK. Vascular calcification in dermatopathology. Am J Dermatopathol. 1979; 1(1): 27-34, indexed in Pubmed: 549478.

11. Fischer AH, Morris DJ. Pathogenesis of calciphylaxis: study of three cases with literature review. Hum Pathol. 1995; 26(10): 1055-1064, indexed in Pubmed: 7557937.
12. NigwekarSU.Calciphylaxis.CurrOpinNephrolHypertens.2017; 26(4): 276-281, doi: 10.1097/MNH.0000000000000328, indexed in Pubmed: 28375870.

13. Cassius C, Moguelet P, Monfort JB, et al. Calciphylaxis in haemodialysed patients: diagnostic value of calcifications in cutaneous biopsy. Br J Dermatol. 2018; 178(1): 292-293, doi: 10.1111/bjd.15655, indexed in Pubmed: 28498603.

14. Nigwekar SU, Zhao S, Wenger J, et al. A Nationally Representative Study of Calcific Uremic Arteriolopathy Risk Factors. J Am Soc Nephrol. 2016; 27(11): 3421-3429, doi: 10.1681/ASN.2015091065, indexed in Pubmed: 27080977.

15. Brandenburg VM, Kramann R, Rothe $\mathrm{H}$, et al. Calcific uraemic arteriolopathy (calciphylaxis): data from a large nationwide registry. Nephrol Dial Transplant. 2017; 32(1): 126-132, doi: 10.1093/ndt/gfv438, indexed in Pubmed: 26908770.

16. Fernández $\mathrm{E}$. [Uremic calcifying ateriolopathy (calciphylaxis) with metabolic syndrome and diabetes mellitus. The current perspective]. Nefrologia. 2008; 28(1): 20-24, indexed in Pubmed: 18336124.

17. Dhanjal TS, Babu SB, Beevers G, et al. Calciphylaxis associated with widespread pulmonary calcification. BMJ Case Rep. 2009; 2009, doi: 10.1136/bcr.09.2008.0880, indexed in Pubmed: 21686585

18. Dominguez AR, Goldman SE. Nonuremic calciphylaxis in a patient with rheumatoid arthritis and osteoporosis treated with teriparatide. J Am Acad Dermatol. 2014; 70(2): e41-e42, doi: 10.1016/.j.jaad.2013.10.013, indexed in Pubmed: 24438979.

19. Fink NR, Pedersen FK, Gyhrs AV. [Symptoms of severe calciphylaxis in a girl with X-linked hypophosphataemia]. Ugeskr Laeger. 2014; 176(21), indexed in Pubmed: 25351902.

20. Hayashi M. Calciphylaxis: diagnosis and clinical features. Clin Exp Nephrol. 2013; 17(4): 498-503, doi: 10.1007/s10157-013-0782-z, indexed in Pubmed: 23430392 
21. Yalin AS, Altiparmak MR, Trabulus $S$, et al. Calciphylaxis: a report of six cases and review of literature. Ren Fail. 2013; 35(1): 163-169, doi: 10.3109/0886022X.2012.741426, indexed in Pubmed: 23151146.

22. Marshall BJ, Johnson RE. Case Report on Calciphylaxis: An Early Diagnosis and Treatment May Improve Outcome. J Am Coll Clin Wound Spec. 2012; 4(3): 67-70, doi: 10.1016/j. jccw.2013.10.001, indexed in Pubmed: 26236639.

23. Burnie R, Smail S, Javaid MM. Calciphylaxis and sodium thiosulphate: a glimmer of hope in desperate situation. J Ren Care. 2013; 39(2): 71-76, doi: 10.1111/j.1755-6686.2013.12008.x, indexed in Pubmed: 23551819.

24. Cai MMX, Smith ER, Brumby C, et al. Fetuin-A-containing calciprotein particle levels can be reduced by dialysis, sodium thiosulphate and plasma exchange. Potential therapeutic implications for calciphylaxis? Nephrology (Carlton). 2013; 18(11): 724-727, doi: 10.1111/nep.12137, indexed in Pubmed: 24571743.

25. Ketteler M, Brandenburg VM. K-alcification Protection in Dialysis Patients: The Underestimated Phenomenon of Vitamin K Deficiency. J Am Soc Nephrol. 2017; 28(6): 1667-1668, doi: 10.1681/ASN.2017020180, indexed in Pubmed: 28373275.

26. Bechara FG, Altmeyer P, Kreuter A. Should we perform surgical debridement in calciphylaxis? Dermatol Surg. 2009;
35(3): 554-555, doi: 10.1111/j.1524-4725.2009.01091.x, indexed in Pubmed: 19250296.

27. An J, Devaney B, Ooi KY, et al. Hyperbaric oxygen in the treatment of calciphylaxis: A case series and literature review. Nephrology (Carlton). 2015; 20(7): 444-450, doi: 10.1111/nep.12433, indexed in Pubmed: 25707425.

28. Ackermann F, Levy A, Daugas E, et al. Sodium thiosulfate as first-line treatment for calciphylaxis. Arch Dermatol. 2007; 143(10): 1336-7; author reply 1338, doi: 10.1001/archderm.143.10.1336, indexed in Pubmed: 17938357.

29. Aihara S, Yamada S, Uchida Y, et al. The Successful Treatment of Calciphylaxis with Sodium Thiosulfate and Hyperbaric Oxygen in a Non-dialyzed Patient with Chronic Kidney Disease. Intern Med. 2016; 55(14): 1899-1905, doi: 10.2169/internalmedicine.55.6326, indexed in Pubmed: 27432100

30. Arenas MD, Gil MT, Gutiérrez MD, et al. Management of calcific uremic arteriolopathy (calciphylaxis) with a combination of treatments, including hyperbaric oxygen therapy. Clin Nephrol. 2008; 70(3): 261-264, indexed in Pubmed: 18793571.

31. Borges L, Rosa P, Dias E, et al. Successful treatment of calciphylaxis by a multidisciplinary approach. BMJ Case Rep. 2014; 2014, doi: 10.1136/bcr-2014-204354, indexed in Pubmed: 25035446. 


\section{Kalcyfilaksja — patogeneza i obraz kiniczny}

Artykuł jest tłumaczeniem pracy: Dubiel-Braszczok B., Włoch-Targońska M., Kotyla P., Calciphylaxis — pathogenesis and clinical picture. Forum Reumatol. 2018 tom 5, nr 1: 14-20.

Należy cytować wersję pierwotną.

Piśmiennictwo znajduje się na stronach 19-20.

\section{STRESZCZENIE}

Kalcyfilaksja - nieuremiczna wapniejąca arteriopatia jest rzadką chorobą naczyń spowodowaną odkładaniem się soli wapniowych w ich ścianach, z towarzyszącymi zaburzeniami krzepnięcia, doprowadzającymi do wystąpienia rozległych owrzodzeń skóry i martwicy tkanek miękkich. Typowe przypadki kalcyfilaksji opisywane są zwykle u chorych na niewydolność nerek, chociaż obecnie wiadomo, że około 1/10 przypad- ków spowodowana jest innymi przyczynami, w tym ogólnoustrojowym stanem zapalnym, zaburzeniami metabolicznymi i endokrynologicznymi. W pracy tej dokonano przeglądu najważniejszych zjawisk patofizjologicznych towarzyszących kalcyfilaksji oraz scharakteryzowano obraz kliniczny choroby i przedstawiono dostępne sposoby postępowania terapeutycznego.

Forum Reumatol. 2019, tom 5, nr 1: 21-26

Słowa kluczowe: kalcyfilaksja; zapalenia naczyń; krańcowa niewydolność nerek

\section{WSTEP}

Kalcyfilaksję, zwaną także uremiczną wapniejącą arteriopatią, opisano po raz pierwszy w XVIII wieku. Współczesny opis i podanie podstaw patogenetycznych zawdzięcza się Hansowi Seyle, który w 1962 roku przeprowadził eksperyment na zwierzętach laboratoryjnych odtwarzając zjawiska patogenetyczne zachodzące w czasie kalcyfilaksji u ludzi $[1,2]$. Jest to występująca stosunkowo rzadko choroba opisywana głównie u chorych na krańcową niewydolność nerek, chorych dializowanych oraz, co trochę nietypowe, chorych po przeszczepieniu nerki [3].

Obraz kliniczny przypomina ciężkie martwicze zapalenie naczyń z głęboką destrukcją tkanki podskórnej, tworzeniem się niegojących owrzodzeń. W literaturze pojawiają się jednak opisy przypadków, które nie są związane z niewydolnością nerek, a w których podkreśla się udział mechanizmów prozapalnych, uszkodzenie śródbłonka czy zachwianie równowagi pomiędzy aktywatorami i inhibitorami wapnienia pozakostnego $[4,5]$.
W niniejszej pracy dokonano przeglądu najważniejszych zjawisk patogenetycznych kalcyfilaksji, wskazując na odmienności przebiegu choroby u chorych z prawidłową funkcją nerek, podkreślając udział podstawowych szlaków zapalnych komórki uczestniczących, co najmniej częściowo, w patogenezie tej rzadkiej choroby.

\section{OBRAZ KLINICZNY}

Obraz kliniczny kalcyfilaksji przypomina ostre, martwicze uszkodzenie naczyń z towarzyszącą martwicą skóry, tkanki podskórnej, z tworzeniem głębokich sączących owrzodzeń, których dno pokryte jest $\mathrm{z}$ reguły masami martwiczymi formującymi czarne stupy. Zmiany skórne wykazują pewną fazowość. Rozpoczynają się zwykle jako siność siateczkowa, następnie ewoluując do postaci guzowatych zgrubień skórnych, ulegają następnie martwicy z wytworzeniem głębokich drążących owrzodzeń [6].

Typowe opisy kalcyfilaksji pochodzą od chorych dializowanych, chorych w krańcowym stadium niewydolności nerek, chociaż również
Adres do korespondencji: dr hab. n. med. Przemystaw Kotyla Katedra i Klinika Chorób Wewnętrznych i Reumatologii Śląski Uniwersytet Medyczny w Katowicach ul Ziołowa 45/47 40-635 Katowice e-mail: pkotyla@sum.edu.pl 
Tabela 1. Za i przeciw zaburzeniom gospodarki mineralnej w patogenezie kalcyfilaksji

\begin{tabular}{|l|l|}
\hline TAK & NIE \\
\hline Niewydolność nerek & Występuje także u chorych bez niewydolności nerek \\
\hline Zaburzenia gospodarki mineralnej & Ulega nasileniu po antykoagulantach doustnych \\
\hline Zaburzenia metaboliczne & Płeć żeńska \\
\hline Inkrustacja ściany naczyniowej solami wapnia & $\begin{array}{l}\text { Występuje w przebiegu układowych chorób tkanki łącznej } \\
\text { (SLE) }\end{array}$ \\
\hline Zła odpowiedź na steroidy i leki immunosupresyjne & Obrazy histopatologiczne, zakrzepica \\
\hline
\end{tabular}

spotyka się je u chorych po przeszczepianiu nerek [4]. Towarzyszące chorobom nerek i długotrwałej dializoterapii zaburzenia gospodarki wapniowo-fosforanowej oraz nadczynność przytarczyc (także pierwotna) uważane są za najważniejsze czynniki patogenetyczne choroby [7]. Analiza rejestrów chorych ze Stanów Zjednoczonych i Europy pokazuje jednak, że choroby nerek, chociaż najczęstsze wśród chorych na kalcyfilaksję, nie odpowiadają za wszystkie przypadki tej choroby. Jak się szacuje u około $10 \%$ chorych na kalcyfilaksję nie udaje się wykazać choroby nerek, a rozwój uszkodzenia naczyń zachodzi niezależnie od stanu czynnościowego nerek. Takie przypadki nazywane są kalcyfilaksją nieuremiczną (non-uremic calcyfilaxis) [8]. W ich mechanizmie powstania uczestniczą zapewne inne zjawiska związane z przewlekłym stanem zapalnym, zaburzeniem krzepliwości i uszkodzeniem śródbłonka.

\section{ROZPOZNANIE}

Rozpoznanie kliniczne jest niezwykle trudne $\mathrm{z}$ uwagi na fakt, że występująca relatywnie rzadko choroba przebiega klinicznie jak typowe martwicze zapalenie naczyń. Można także przypuszczać, że znikoma częstość rozpoznawania kalcyfilaksji jest przynajmniej częściowo spowodowana mylnym klasyfikowaniem kalcyfilaksji jako opornego na leczenie zapalenia naczyń. Dlatego też w procesie diagnostycznym istotną rolę odgrywa dobrze zebrany wywiad (niewydolność nerek, dializoterapia pierwotna i wtórna nadczynność przytarczyc hyperwitaminoza $\mathrm{D}_{3}$ ) [9]. Jednak ostateczne rozpoznanie można postawić po wykonania bioptatów zajętej skóry oraz wykazania w nim typowych zmian histopatologicznych. Obrazy te obejmują martwicę skóry, tkanki podskórnej, zapalne nacieki w tkance tłuszczowej. Najbardziej charakterystyczne i cenne z punktu widzenia diagnostycznego jest wykazanie w obrębie zmienionych naczyń inkrustacji solami wapnia $\mathrm{z}$ towarzyszącym rozplemem błony środkowej, jej włóknieniem oraz zmianami zakrzepowymi we wnętrzu naczyń [10] (tab. 1).

Badanie histopatologiczne chociaż dające $\mathrm{w}$ istocie niepodważalne rozpoznanie, w praktyce klinicznej może być mocno kontrowersyjne. U chorych $\mathrm{z}$ kalcyfilaksją proces gojenia nawet niewielkich ran chirurgicznych przebiega bardzo trudno - istnieje więc ryzyko dalszego uszkodzenia skóry pacjentów i nasilenia niedokrwiennych zmian skórnych. Dlatego też poszukuje się metod alternatywnych, jak ultrasonografia naczyń, wykazująca gromadzenie soli wapnia w ścianie naczyń, wykazanie zapalnych ognisk tkanki tłuszczowej, scyntygrafia kości czy zwykłe badanie radiologiczne kończyn wykazujące wysycenie wapniem ściany naczyniowej oraz paciorkowate złogi soli wapnia na przebiegu naczyń [11].

\section{CZYNNIKI RYZYKA}

Na podstawie dostępnych danych literaturowych, w tym opisów pojedynczych przypadków i charakterystyki liczbowo ograniczonych serii przypadków, udało się zidentyfikować czynniki ryzyka mogące mieć udział w patogenezie choroby. Są nimi oprócz wspomnianej niewydolności nerek niektóre choroby nowotworowe, alkoholowe uszkodzenie wątroby zapalne choroby stawów, układowe choroby tkani łącznej. Niewydolność nerek, a także przewlekły program dializ, mogą odpowiadać za proces uwapniania ściany naczyniowej [12]. W przebiegu niewydolności nerek dochodzi do zwiększenia retencji fosforanów, wtórnej nadczynności przytarczyc oraz substytucji soli wapnia. Nadmierna podaż preparatów wapniowych wiazząacych fosforany, nieadekwatnie dobrany skład płynów dializacyjnych u osób predysponowanych mogą prowadzić do rozwoju kalcyfilaksji. Nie budzi więc zdziwienia, że typowe opisy kalcyfilaksji dotyczą chorych z krańcową niewydolnością nerek oraz chorych dializowanych $[4,13]$. Na podstawie ana- 
lizy stężeń wapnia i fosforanów oszacowano, że ryzyko wystąpienia choroby jest szczególnie duże, gdy iloczyn wapń $\mathrm{X}$ fosforany przekracza wartość $60 \mathrm{mg}^{2} / \mathrm{dl}^{2}$. Analizy rejestrów medycznych wskazują, że ryzyko wystąpienia tego powikłania wynosi 3,5/1000 pacjentolat wśród chorych z krańcową niewydolnością nerek [14]. Według rejestrów niemieckich obserwuje się w grupie chorych z niewydolności nerek około 30 nowych przypadków rocznie - należy przypuszczać, że liczba takich przypadków w Polsce będzie zbliżona [15].

Nie wszystkie jednak przypadki choroby występują $\mathrm{u}$ chorych $\mathrm{z}$ istotnie upośledzoną czynnością nerek. Około $10 \%$ przypadków kalcyfilaksji przypada na osoby z prawidłową lub tylko nieznacznie upośledzoną czynnością nerek, u których nie należy spodziewać się występowania poważnych zaburzeń osi wapń-fosfor-przytarczyce. Cytowany już rejestr niemiecki przypadków kalcyfilaksji pokazuje, że nawet $20 \%$ przypadków kalcyfilaksji występuje u osób z GFR powyżej $60 \mathrm{ml} / \mathrm{min}$ [15]. Niestety nie dysponujemy obecnie kliniczną charakterystyką pacjentów z kalcyfilaksją w przebiegu chorób nerek i osób z zachowaną czynnością tego narządu. Trudno więc wyciągnąć jakiekolwiek wnioski. Należy jednak przypuszczać, że chorzy z niewydolnością nerek i pacjenci $\mathrm{z}$ zachowaną funkcją wydalniczą narządu mogą stanowić dwie niezależne jednostki kliniczne, posiadające podobny obraz chorobowy. Pokazuje to, że również inne mechanizmy choroby należy wziąć pod uwagę. Dla tej grupy chorych zidentyfikowano inne czynniki ryzyka, wiążące zaburzenia metaboliczne (np. otyłość, cukrzyca), przewlekły stan zapalny (zapalenie w alkoholowym uszkodzeniu wątroby), stosowanie niektórych leków (immunosupresyjnych, cytostatycznych glikokortykosteroidów) czy występowanie zjawisk autoimmunizacyjnych [16-19]. Listę aktualnie znanych czynników ryzyka zebrano w tabeli 2 .

\section{RÓŻNICOWANIE}

Obraz kliniczny przypomina bardzo aktywne, agresywne zapalenie naczyń z martwicą skóry i głębokimi owrzodzeniami. Obie choroby są praktycznie nie do odróżnienia klinicznie, dlatego też rozpoznanie bazuje na wyniku badania histopatologicznego, z wykazaniem złogów wapnia w obrębie błony środkowej. Wapnienia w ścianie tętnic zmuszają do różnicowania kalcyfilaksji z miażdżycą.
Tabela 2. Przyczyny kalcyfilaksji nieuremicznej

\begin{tabular}{|c|}
\hline Przyczyny kalcyfilaksji nieuremicznej \\
\hline Nadczynność przytarczyc \\
\hline $\begin{array}{l}\text { Nowotwory: } \\
\text { - } \text { pęcherzyka żółciowego } \\
\text { - } \text { przewlekła białaczka szpikowa } \\
\text { - } \\
\text { - } \\
\text { - innerniak złośliwy } \\
\end{array}$ \\
\hline Alkoholowe uszkodzenie wątroby \\
\hline $\begin{array}{l}\text { Układowe choroby tkanki łącznej: } \\
\text { - toczeń } \\
\text { - RZS } \\
\text { - zapalenie tętnicy skroniowej } \\
\text { - zespól antyfosfolipidowy }\end{array}$ \\
\hline Cukrzyca \\
\hline Otyłość \\
\hline Zespól POEMS \\
\hline Pleć żeńska \\
\hline $\begin{array}{l}\text { Leki: } \\
\text { - immunosupresyjne } \\
\text { — glikokortykosteroidy } \\
\text { — doustne antykoagulanty (bazujące na inhibicji witami- } \\
\quad \text { ny K) }\end{array}$ \\
\hline
\end{tabular}

$\mathrm{W}$ tej ostatniej wapnienie zachodzi jednak śródnaczyniowo i wiąże się z obecnością blaszek miażdżycowych. W kalcyfilaksji dotyczy natomiast błony środkowej. Biorąc pod uwagę średnicę zajętych naczyń, trzeba podkreślić, że zmiany typowe dla kalcyfilaksji dotyczą naczyń o średnicy mniejszej niż $0,6 \mathrm{~mm}$ w równym stopniu zarówno arteriol, jak i kapilar skórnych z typowym zajęciem przez złogi wapnia błony środkowej.

Mało charakterystyczny obraz kliniczny zmusza do szerokiego różnicowania ze wszystkim jednostkami chorobowymi, w przebiegu których może dochodzić do rozległego uszkodzenia skóry [20-22] (tab. 2).

\section{PATOGENEZA}

Krańcowa niewydolność nerek i zaburzenie metaboliczne przez nią wywołane mają największy udział w zapoczątkowaniu destrukcji naczyń. Takie rozumienie choroby jest jednak mocnym uproszczeniem [4]. Procesy uszkadzające rozpoczynają się na poziomie śródbłonka (ryc. 1.). Towarzyszą im zjawiska nadkrzepliwości krwi, zwiększonej gotowości organizmu do formowania pozakostnych obszarów kalcyfikacji. Procesy wapnienia tkankowego regulowane są przez sprawnie działający mechanizm zapobiegający tworzeniu pozakostnych obszarów mineralizacji. System ten składa się 
Tabela 3. Rozpoznanie różnicowe kalcyfilaksji

\begin{tabular}{|l|l|}
\hline \multicolumn{2}{|l|}{ Rozpoznanie różnicowe kalcyfilaksji } \\
\hline $\begin{array}{l}\text { Martwica skóry wywołana } \\
\text { warfaryną }\end{array}$ & Ustępuje po odstawieniu warfaryny \\
\hline Zespół antyfosfolipidowy & Typowa konstelacja objawów klinicznych laboratoryjnych z obecnością przeciwciał \\
\hline Miażdżyca małych naczyń & Słabe/brak tętna, chłodne kończyny, chromanie przestankowe \\
\hline Owrzodzenie pourazowe & $\begin{array}{l}\text { Nieregularny kształt, zwykle brak siności siateczkowej, wywiad w kierunku urazu, } \\
\text { najczęściej lokalizowana na przedniej powierzchni podudzia }\end{array}$ \\
\hline $\begin{array}{l}\text { Owrzodzenie z niewydolnością } \\
\text { żylną }\end{array}$ & $\begin{array}{l}\text { Kształt nieregularny, dno pokryte wilgotnym włóknikiem żylaki kończyn dolnych, złogi } \\
\text { hemosyderny w otaczającej skórze }\end{array}$ \\
\hline Owrzodzenie neuropatyczne & $\begin{array}{l}\text { Owrzodzenie zlokalizowane w miejscach ucisku, nieprawidłowości stwierdzane w bada- } \\
\text { niu neurologicznym (zaburzenia czucia, dotyku wibracji temperatury czasami deforma- } \\
\text { cje o typie stawów Charkota) }\end{array}$ \\
\hline Układowe zapalenie naczyń & $\begin{array}{l}\text { Układowy charakter objawów z zajęciem narządów wewnętrznych, dodatnie przeciwcia- } \\
\text { ła przeciwcytoplazmie granulocytów obojętnochłonnych (ANCA) }\end{array}$ \\
\hline $\begin{array}{l}\text { Martwica skóry wywołana } \\
\text { heparyną }\end{array}$ & $\begin{array}{l}\text { Pojawia się po około 2 tygodniach od rozpoczęcia leczenia heparyną, głównie w miej- } \\
\text { scach iniekcji heparyny towarzyszy jej istotne zmniejszenie liczby płytek (< 50 000) }\end{array}$ \\
\hline Krioglobulinemia & Zajęcie przyśrodkowej i/lub bocznej powierzchni uda, zmiany w proteinogramie \\
\hline $\begin{array}{l}\text { Rozsiany zespól wykrzepiania } \\
\text { wewnątrznaczyniowego }\end{array}$ & $\begin{array}{l}\text { Rozsiane zmiany skórne z trombocytopenia i istotnym zwiększeniem stężenia D-dime- } \\
\text { rów, głębokimi zmianami w wynikach badań laboratoryjnych układowy charakter zmian }\end{array}$ \\
\hline $\begin{array}{l}\text { Zakrzepowa plamica małopłyt- } \\
\text { kowa }\end{array}$ & $\begin{array}{l}\text { Rozpoczyna się odsiebnie wykazuje tendencje do rozprzestrzeniania się proksymalnego, } \\
\text { liczba płytek wyraźnie obniżona, wysoka aktywność LDH }\end{array}$ \\
\hline
\end{tabular}

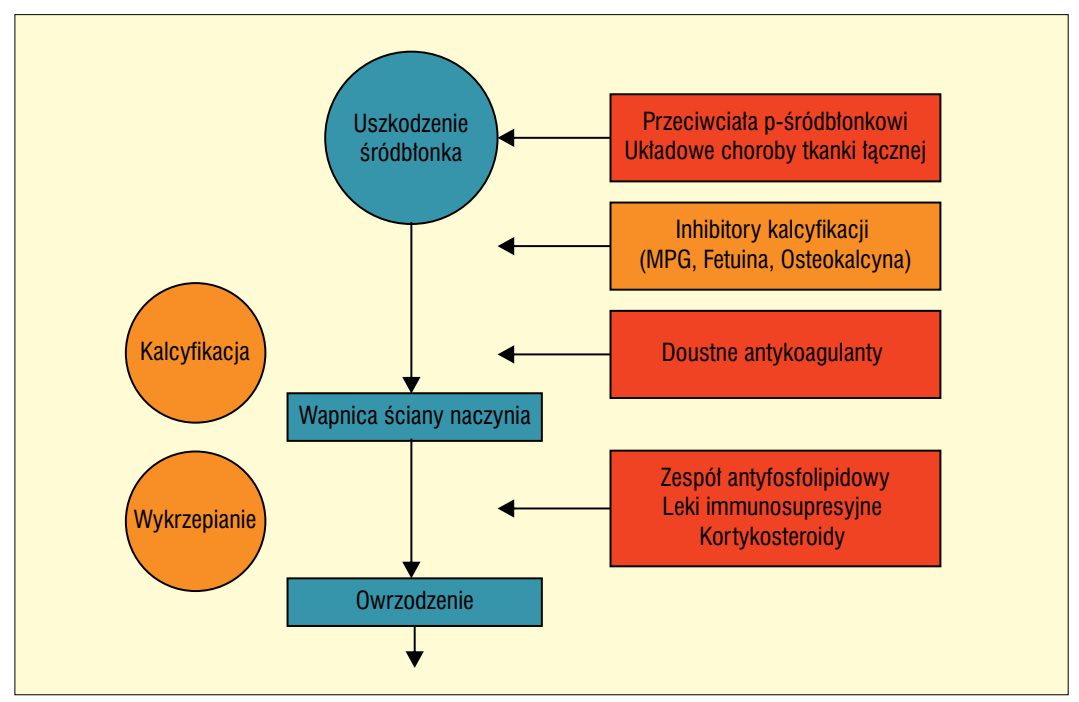

Rycina 1. Rola śródbłonka w rozwoju kalcyfilaksji

głównie z białka macierzowego Gla (MGP, Matrix GLa Protein), będącego silnym inhibitorem uczestniczącego w wapnieniu pozakostnym białka morfogenicznego kości 2 (BMP-2, bone morfogenic protein 2) [15, 23, 24]. Ten sprawny mechanizm działa tylko w przypadku potranslacyjnej modyfikacji białka MGP, co zachodzi za sprawą gamma karboksylacji białek. W procesie tym (analogicznie jak w przypadku czynników krzepnięcia) bierze udział witamina $\mathrm{K}$ będąca kofaktorem gamma-karboksylazy. W przypadkach niedoboru witami- ny K lub częściej stosowania antykoagulantów, będących kompetycyjnymi inhibitorami witaminy $\mathrm{K}$, proces karboksylacji nie jest w pełni realizowany, a białka MGP nie są karboksylowane lub karboksylowane są tylko częściowo. Innymi inhibitorami wapnienia pozakostnego są fetuina i osteokalcyna, przy czym w procesach wapnienia naczyniowego rolę odgrywa tylko ta pierwsza [24]. Działanie osteokalcyny jest raczej systemowe, a jej cząsteczka jest zbyt duża, aby mogła uczestniczyć w lokalnym zahamowaniu wapnienia [25]. 
Analizując obrazy zajętych naczyń, zwraca uwagę specyficzne rozmieszczenie soli wapnia odróżniające tę chorobę od waskulopatii w przebiegu osteodystrofii czy typowych wapniejących blaszek miażdżycowych. W odróżnieniu od dwóch pozostałych, w kalcyfilaksji proces ten dotyczy błony wewnętrznej, a poprzedzony jest zmianą fenotypu komórek mięśni gładkich naczynia w kierunku komórek osteoblasto-podobnych (osteoblast-like). Komórki osteoblasto-podobne wykazują dużą wrażliwość na działanie czynników warunkujących wzmożoną mineralizację tkankową. Proces ten jest dodatkowo regulowany przez osteopontynę i białko morfogeniczne kości 4 (BMP-4), które uczestniczą w procesach rozwoju i reperacji uszkodzeń kostnych, jak również uważa się je za wskaźnik transformacji komórki w kierunku osteoblastów. Stężenie osteopontyny podlega regulacji za pośrednictwem czynnika transkrypcyjnego NF- $\kappa \mathrm{B}$, którego aktywność wzrasta na skutek działania cytokin prozapalnych i wolnych rodników.

Takie przedstawienie procesów patogenetycznych zbliża rozumienie kalcyfilaksji do zwyklej krystaloarteriopatii (nazwa utworzona dla podkreślenia analogii do krystaloartropatii) — jako że w obu chorobach dominuje odkładanie soli wapniowych odpowiednio w ścianie naczyniowej i błonie maziowej stawu) (tab. 1).

W świetle ostatnich doniesień takie mechanistyczne rozumienia choroby jest znacznym uproszczeniem. Nowe światło na zrozumienie patogenezy choroby rzucily obserwacje wskazujące na bardzo częste występowanie zaburzeń krzepnięcia (ok. $60 \%$ wszystkich przypadków kalcyfilaksji). Zwiększone pogotowanie prozakrzepowe (związane np. z niedoborem inhibitorów krzepnięcia lub inną formą trombofilii). Wśród stwierdzanych zaburzeń krzepnięcia zwraca uwagę występowanie niedoborów antytrombiny (50\%), następnie niedobory aktywności białek $\mathrm{C}$ i S (odpowiednio 38 i 43\%). Zmiana charakteru śródbłonka z przeciwzakrzepowego na prozakrzepowy może być również spowodowana lokalnym działaniem prozapalnych cytokin — zwłaszcza IL-11, IL-6 i TNF-alfa. Zwiększone stężenia tych cytokin mogą być wynikiem ogólnoustrojowego procesu zapalnego oraz zaburzeń metabolicznych lub endokrynologicznych (ryc. 1).

\section{ZNACZENIE WITAMINY K}

Jak wspomniano u większości chorych na kalcyfilaksję stwierdza się zaburzenia krzep- nięcia krwi, często z poważnymi epizodami niedokrwiennymi w wywiadzie. $Z$ tego też powodu, jak również ze względów najczęściej kardiologicznych, pacjenci ci otrzymują stosowne leczenie przeciwzakrzepowe, bazujące głównie na antagonistach witaminy K. Okazuje się jednak, że stosowanie antagonistów witaminy $\mathrm{K}$ w istotny sposób nasila zmiany naczyniowe, a grupa leczona w ten sposób charakteryzuje się gorszym przebiegiem i poważniejszym rokowaniem. Patogenetyczne podstawy niekorzystnego działania antagonistów witaminy $\mathrm{K}$ spowodowane są blokowaniem działania witaminy $\mathrm{K}$ jako kofaktora gamma karboksylacji i wyłączenia ochronnego działania inhibitorów wapnienia (głównie MGP), które również muszą ulec karboksylacji dla utrzymania ich fizjologicznego działania. W przypadku konieczności leczenia przeciwzakrzepowego zaleca się stosowanie bezpośrednich antykoagulantów działających na poziomie trombiny, a omijających etapy czynników krzepnięcia zależnych od witaminy $\mathrm{K}$.

\section{ROKOWANIE}

Kalcyfilaksja jest potencjalnie śmiertelną chorobą - połowa pacjentów umiera w ciągu pierwszego roku choroby, dwa lata przeżywa tylko jedna piąta. Najczęstszymi przyczynami śmierci są powikłania septyczne, spowodowane rozległością niegojących się ran. Chociaż nie ma różnic w krzywych przeżycia pomiędzy chorymi ze zmianami proksymalnymi w porównaniu ze zmianami obwodowymi, to jednak chorzy z oboma typami zmian charakteryzują się znacznie gorszym rokowaniem (co zapewne wynika z rozległości uszkodzeń skóry). Również chorzy z kalcyfikacją w obrębie prącia cechują się wyraźnie zwiększoną śmiertelnością w okresie jednego roku (69\%). Przyczyna tego zjawiska nie jest znana.

\section{LECZENIE}

1. W postępowaniu leczniczym podstawowe znacznie ma kontrola stanu zapalnego, co można zrealizować, stosując:

- szerokospektralną antybiotykoterapię;

- opracowanie chirurgiczne ran [26];

- leczenie w komorze hiperbarycznej [27].

2. Bardzo istotnym elementem postępowania terapeutycznego jest walka z bólem:

— z uwagi na dramatyczny przebieg zaleca się stosowanie opiatów, unikając w mia- 
rę możliwości morfiny, która dodatkowo może zmniejszać perfuzję tkankową. Lekiem $\mathrm{z}$ wyboru jest fentanyl, który w okresie wymiany opatrunków można uzupełnić innym opiatem.

3. Pamiętając o często występujących zaburzeniach krzepnięcia, leczenie antykoagulacyjne należy uznać za jeden z podstawowych składników postępowania medycznego. Należy mieć na uwadze szczególne niekorzystne działania antagonistów witaminy $\mathrm{K} \mathrm{u}$ chorych na kalcyfilaksję:

- doustne leki przeciwkrzepliwe są w przebiegu kalcyfilaksji przeciwskazane. W przypadkach konieczności leczenia przeciwkrzepliwego można zastosować heparynę, a w razie leczenia długotrwałego leki oddziałujące bezpośrednio na kompleks protrombiny.

4. Zwalczanie zaburzeń gospodarki mineralnej:

— w przypadkach kalcyfilaksji zależnych od zaburzeń osi wapń-fosfor-parathormon konieczne jest wyrównanie tych zaburzeń. W celu zmniejszenie stężenia wapnia warto rozważyć zastosowanie tak zwanych kalcymimetyków, czyli leków uwrażliwiających receptor wapniowy i powodujących zmniejszenie stę- żenia wapnia. Dobre efekty przynoszą wlewy tiosiarczanu sodowego (sodium thiosulfate) w dawce $25 \mathrm{~g} 3$ razy w tygodniu [23]. W przypadku pacjentów dializowanych zmiana programu dializ oraz modyfikacja składu płynu dializacyjnego oraz rozważenie zmiany sposobu dializowania (preferowana hemodializa nad dializą otrzewnowa) [28-31].

\section{PODSUMOWANIE}

Kalcyfilaksja jest rzadką chorobą opisywaną głównie u chorych z krańcową niewydolnością nerek, u których czynnikiem sprawczym są głębokie zaburzenia gospodarki mineralnej. Około $10 \%$ przypadków przypada na kalcyfilaksję u chorych $\mathrm{z}$ prawidłową czynnością nerek, co pokazuje, że zaburzenia osi wapniowo-fosforanowej nie są uniwersalnym mechanizmem patogenetycznym. Choroba wymaga prowadzenia szerokiego postępowania różnicowego, które winno brać pod uwagę wszystkie choroby, w przebiegu których dochodzi do martwicy skóry. W przypadkach podejrzenia kalcyfilaksji należy unikać antagonistów witaminy $\mathrm{K}$ oraz nie stosować glikokortykosteroidów oraz leków immunosupresyjnych z uwagi na możliwość zaostrzenia obrazu chorobowego. 